University of Wollongong

Research Online

Faculty of Business - Papers (Archive)

Faculty of Business and Law

$1-1-2016$

The Informativeness of Substantial Shareholder Trading in the Lead up to a Takeover Bid

Millicent M. Chang

University of Western Australia, mchang@uow.edu.au

Raymond Da Silva Rosa

University of Western Australia

Wilson $\mathrm{Ng}$

University of Western Australia

Follow this and additional works at: https://ro.uow.edu.au/buspapers

Part of the Business Commons

Research Online is the open access institutional repository for the University of Wollongong. For further information contact the UOW Library: research-pubs@uow.edu.au 


\title{
The Informativeness of Substantial Shareholder Trading in the Lead up to a Takeover Bid
}

\begin{abstract}
Although substantial shareholders are often considered quasi-insiders, not much is known about the information they possess, especially around changes in corporate control events. We examine whether substantial shareholders in target firms possess information about future takeover activity and if they have such information, whether they trade opportunistically on it. The results show increased purchases by substantial shareholders close to a takeover announcement where these trades predict the likelihood of takeovers. However, they do not predict bid premiums nor other deal characteristics. A comparison of different types of substantial shareholders indicates that institutional shareholder trades are better indicators of takeover likelihood relative to the trades of managerial shareholders. These findings imply that substantial shareholders are indeed quasi insiders who have an informational advantage over other shareholders about future takeover activity and they use this advantage for their own benefit.

\section{Keywords}

trading, bid, lead, informativeness, takeover, substantial, shareholder, up

\section{Disciplines}

Business

\section{Publication Details}

Chang, M. M., Da Silva Rosa, R. \& Ng, W. (2016). The Informativeness of Substantial Shareholder Trading in the Lead up to a Takeover Bid. The 28th AsianFA Conference 2016 (pp. 1-39). United States: Elsevier.
\end{abstract}


The Informativeness of Substantial Shareholder Trading in the Lead up to Takeover Bids

\author{
Millicent Chang ${ }^{1}$ \\ UWA Business School \\ The University of Western Australia \\ Email: millicent.chang@uwa.edu.au \\ Raymond da Silva Rosa \\ UWA Business School \\ The University of Western Australia \\ Email: ray.dasilvarosa@uwa.edu.au \\ Wilson $\mathrm{Ng}$ \\ Email: wilson.ng1994@gmail.com
}

\begin{abstract}
We examine whether substantial shareholders in target firms possess information about imminent takeover activity and if they do, whether they trade opportunistically on the information. The results show increased purchases by substantial shareholders close to a takeover announcement where these trades predict the likelihood of takeovers. However, they do not predict bid premiums nor other deal characteristics. Comparing type of substantial shareholder, institutional trades are better indicators of takeover likelihood compared to managerial trades. These findings imply that some substantial shareholders have an informational advantage about takeover activity and they use it for their own benefit.
\end{abstract}

Keywords: substantial shareholders, takeovers, information trading

JEL: G14, G34

${ }^{a 1}$ Corresponding author 


\section{Introduction}

We study substantial shareholder trading activity in target firms in the lead up to takeover bids to determine whether these shareholders possess bid information and whether they are able to profit from access to this information. Like others, we speculate that substantial shareholders have informational advantage over other shareholders. According to Shleifer and Vishny (1997), they may be semi-informed traders, having access to private information via privileged meetings with management or because of their increased levels of monitoring and processing ability. Although untested, the assumption that these shareholders have an information advantage is implicit in legislation, requiring shareholders holding five percent or more of a firm's outstanding shares to disclose their trading to the firm and the market (Corporations Act (Cth) 2001). Takeover bids typically incorporate a substantial premium for control (Laamanen 2007) and if substantial shareholders have informational advantage, they may have foreknowledge of upcoming bids and trade accordingly to maximise return.

In a related study, Agrawal and Nasser (2012) find that while insiders in the U.S. tend to decrease their purchases prior to a bid, they decrease their sales to a greater magnitude. This 'passive trading' results in a positive level of net purchases which profits the insiders. If substantial shareholders trade prior to a bid, the next step is to determine whether these trades are predictive of the upcoming bid. The literature on takeover likelihood has focused primarily on firm specific characteristics (see for example, Palepu 1986; Powell 1997; Rodrigues \& Stevenson 2013). Changes in holdings due to private information can themselves contain information (Chakravarty 2001) since Keown and Pinkerton (1981) find that information leakages occur prior to merger announcements through trading. If a substantial shareholder has access to information about a future bid and details of the bid in particular the bid premium, their trades may also signal this information. However, Aspris et al. (2014) assert that substantial shareholder trading is not predictive of a takeover bid where trading is measured by its presence. We challenge this using a more comprehensive measure of trading and by categorising the substantial shareholder group into institutional, managerial, financial and other to better understand the trading incentive.

Our results show that substantial shareholders possess foreknowledge of future takeover activity, as indicated by increases in their purchases prior to the bid announcement. 
Furthermore, substantial shareholder trading behaviour significantly improves the rate of predictive success. However, such trading behaviour is uninformative about the bid premium, or other deal characteristics such as the payment method or terms of the deal. These results suggest that while substantial shareholders are better informed about the probability of imminent takeover bids, they do not appear to be privy to detailed aspects of bids such as the premium, payment method or deal terms.

We find no evidence that managerial shareholders change their trading behaviour more than other substantial shareholders prior to a bid. While they exhibit little evidence of active or passive trading, in contrast, financial institution and other corporation shareholders trade to actively increase their holdings in the pre-bid period. Overall, these results indicate that substantial shareholders are aware of future takeover activity. While substantial shareholders may hold an informational advantage, they may not trade on it. Managerial substantial shareholders, those likely to have greatest access to private information avoid acting on such information, most likely due to firm monitoring and scrutiny, together with additional disclosure requirements.

This study is structured as follows. A review of the relevant literature concerning the proposed informational advantage possessed by substantial shareholders, takeover likelihood, acquisition premiums and the role of substantial shareholders in takeover situations is presented in Section 2. In Section 3, hypotheses are developed and Section 4 details the data and sample used. A description of the method used is provided in Section 5 while the results are given in Section 6. Section 7 concludes with a summary, a discussion of the limitations and suggestions for future research.

\section{Review of literature and hypotheses}

Several studies predict and find substantial shareholder trading is akin to trading by insiders. Shleifer and Vishny (1997) observe that substantial shareholders may hold an informational advantage through access to private information from involvement in firm governance or privileged meetings with management. An informational advantage could also originate from these shareholders investing more resources in monitoring because their substantial holdings gives them an incentive to do so (Holderness 2003) and affords them economies of 
scale. This interpretation fits with McKinnon and Dalimunthe (1993) reporting a negative relationship between firm voluntary disclosures and blockholder ownership. High blockholder ownership provides more opportunities and incentive for shareholders to intervene if management and shareholder interests misalign so the need for information disclosure is reduced. On the other hand, the lower level of disclosure could be a way of preserving the informational advantage of block holders.

Having an incentive to monitor does not imply direct action to intervene. Edmans (2009) posits that substantial shareholders are able to exert governance indirectly without intervening in a firm's operations. Instead they are able to impound information into prices by selling their stakes on negative information (Edmans 2009). This action, also known as the Wall Street Walk, involves selling out ownership rather than taking a direct role in governance (Admati \& Pfleiderer 2009). This increases the liquidity available to substantial shareholders and their ability to trade.

Several empirical studies support the proposition that large shareholders have an informational advantage. Brockman and Yan (2009) find that in the US, the probability of informed trading increases with higher levels of block ownership (defined as ownership of greater than ten percent of a firm's outstanding voting shares). Heflin and Shaw (2001) draw a similar conclusion of the relationship between block ownership and adverse selection spread components. They find that smaller investors are more wary of trading with large, presumably more informed investors.

Further evidence of substantial shareholder trades reflecting an informational advantage is documented by Zeckhauser and Pound (1990), Bushee and Goodman (2007) and Piotroski and Roulstone (2005) who find significant association between substantial shareholder trades in the US and returns based on return-on-equity, return-on-assets, as well as future performance. Gallagher et al. (2013) document similar findings in Australia, where institutional substantial shareholders earn significant positive market adjusted returns.

A closely related study, Aspris et al. (2014), tests the power of substantial shareholder trades to predict pre-bid price runups. The pre-bid trading activity they assess includes bidder trades that result in substantial shareholder status in the target firm (i.e. holding $5 \%$ 
or more of the outstanding votes) and trading activity by all substantial shareholders that cause their holdings to change by one percent or more and thereby trigger a mandatory reporting requirement. They record toehold acquisition to indicate if the acquiring firm reached a five percent or greater holding of the target firm over a long or short period prior to the bid. They find that while only short term toehold acquisitions have a significant relationship with the pre-bid price runup, the effect is not robust to the toehold effect documented by Bishop (1991). Specifically, Bishop (1991) argues that toehold acquisitions revise the market's anticipation of a takeover bid, while not necessarily signalling a bid.

Aspris et al. (2014) measure substantial shareholder activity in two ways; first, they study an acquirer's toehold acquisition, that is, an acquisition reaching five percent of the firm's outstanding interest (by definition, becoming a substantial shareholder), and use a dichotomous variable to indicate this occurrence. Second, they consider trading by other substantial shareholders, again measuring this through a dichotomous variable.

$\mathrm{H}_{1}$ : Substantial shareholders increase their holdings in target firms prior to a takeover bid.

Substantial shareholders have access to superior information because they have both the incentive to expend resources in information search and privileged access to managers. These advantages, in particular privileged access to information, are likely to be higher for substantial shareholders who are also "insiders" (e.g., directors and managers). If so, the relationship between pre-bid purchases and insider shareholders is likely to be stronger than for other substantial shareholders such as financial institutions or other corporations.

$\mathrm{H}_{1 \mathrm{a}}$ : Insider shareholders increase their holdings in target firms more than other substantial shareholders prior to a takeover bid.

The ability to predict takeovers has been the focus of a substantial body of research as takeovers have a substantial impact on the various stakeholders within and related to the firm, as well as substantial potential return for target shareholders. Asquith (1983) documents a significant increase in target firm share prices prior to the announcement of a 
bid. This indicates that the market is unable to fully predict upcoming takeover bids as the higher valuation is not already impounded in prices. This observation leads to the question: Why are firms acquired? In asking this question, the literature examines various fundamental drivers of takeovers and their ability to predict the likelihood of a takeover occurring. While there exist multiple hypotheses explaining the likelihood of a takeover, many explanations produce mixed results in empirical analysis, indicating the difficulty of predicting takeover outcomes, and the potential gains that holders of private information may achieve.

One of the most widely cited reasons for takeovers is inefficient management. Manne (1965) argues for a strong positive relationship between the efficiency of a firm's management and share price. This may be acted on by competitors and other management teams. Fama (1980) explains that inefficient firms are targeted by such competition as investment opportunities in order to improve efficiency and performance. Another reason for takeover as documented by Manne (1965) is the 'recent performance' hypothesis. The 'recent performance' hypothesis interprets a firm's lower returns as a signal that the market believes recent performance has been poor. With respect to this poor market performance, Manne (1965) argues that the stock price is the market's signal for a change in management, and a capital gain linked to the potential value of the firm under competent management.

The growth resource mismatch hypothesis can be explained as firms whose resources and growth opportunities do not match. ${ }^{2}$ Jensen (1986) suggests that firms with less growth opportunities but more resources are more likely to become takeover targets as management may tend to engage in negative NPV projects instead of repaying shareholders in dividends or repurchases as this would reduce resources under management control. A common proxy used to measure the growth resource mismatch is by comparing sales growth to a firm's liquidity ratio, used by both Palepu (1986) and Powell (2001). While both studies find a significant result, Ambrose and Megginson (1992) find that the growth

\footnotetext{
${ }^{2}$ Two possible scenarios can occur: a firm with the capability to invest but a lack of positive net present value (NPV) projects to invest in (low growth but high resource), or a firm with a opportunities to invest in positive NPV projects but lack the funds to do so (high growth but low resource) (Palepu 1986)
} 
resource mismatch hypothesis has little significance in their random sample of US firms from 1981 to 1992. A firm's optimal capital structure is difficult to determine and many theories exist. The trade-off between levels of debt and equity is discussed by a number of theories, however the underlying requirements are that marginal benefits should equal marginal costs of utilising either debt or equity (Myers 1984). Barnes (1999) posits that making an acquisition could be used as an alternative route to changing the firm's capital structure, and as such reduces inefficiencies. If a firm has reached its debt capacity, it may benefit from taking over another firm with unused debt capacity.

Takeovers have often been observed to occur clustered in groups through time and within industries. Gort (1969) suggested that clustered M\&A activity could be due to economic disturbances within industries over certain periods of time. Palepu (1986) further submits that industry disturbances may be short lived, with the emergence of potential targets within disturbances quickly consumed by the increased M\&A activity. In an Australian study by da Silva Rosa et al. (2006), a significant takeover wave effect is also found. Alternative views point to the effects of size on acquisition likelihood; Palepu (1986) suggesting that the likelihood of a firm being acquired is negatively associated with size. This can be attributed to the transaction and integration costs of acquiring large firms; the stronger ability for larger firms to defend themselves against acquirers fundamentally limited the ability of an acquirer to acquire the target.

While many of the above provide strong explanatory power in modelling the probability of a takeover bid occurring, few explanations have improved the rate of correct predictions of the model beyond that of chance. Previous takeover predictability models utilise firm characteristics to proxy for driving forces of takeovers such as the use of accounting ratios in logit models, as in early takeover likelihood models by Stevens (1973) and Belkaoui (1978). Palepu (1986) revisits such early models, identifying methodological issues. He proposes that they lack strong theoretical explanations for including particular variables, leading to 'over-fitting' the model with statistically significant variables that do not necessarily improve predictability performance. The method of random sampling used in previous models to match target and non-target firms by industry and size may produce a sample selection bias in prediction tests. It would be desirable to use the entire population of firms as sampling 
and matching firms would produce a higher proportion of targets to control firms. However while the matching of target and control firms is not advised in the development of prediction tests, Manski and McFadden (1981) as well as Palepu (1986) recommend using this technique in determining significance of the various factors used to estimate the model. A substantial shareholder's purchase ratio reveals their aggressiveness in trades (Zhang et al. 2005). Higher pre-bid purchases allow a substantial shareholder to profit more from the premium offered in a takeover and so it is plausible that higher substantial shareholder purchase ratios predict bids. This leads to the second hypothesis:

$\mathrm{H}_{2}$ : Substantial shareholders' purchases are positively related to the likelihood of a takeover bid.

Shleifer and Vishny (1997) note that access to information is not necessarily equal across different categories of substantial shareholders. Some acquire private information through insider status, while others use their resources to more accurately analyse public information. Insiders are likely to be better placed than outsiders in accessing pertinent information (Meulbroek 1992). This leads to an extension of hypothesis $\mathrm{H}_{2}$ :

$\mathrm{H}_{2 \mathrm{a}}$ : Insider shareholders' purchases are more closely associated with a subsequent takeover bid than the net purchases ratio of other substantial shareholders.

Research on acquisition premiums has found a substantial number of factors that influence premiums. If substantial shareholders hold an informational advantage regarding future takeover activity, it is expected that they would increase their net purchases to acquire a larger premium. The cash consideration hypothesis predicts firms that receive a cash bid are offered a higher premium because receiving cash triggers tax liabilities for target shareholders and so they require a higher premium relative to share bids to accept the offer. Brown and Ryngaert (1991) in the US and (Bugeja \& da Silva Rosa 2008) document evidence that supports this argument. Manne (1965) discussion of the recent performance hypothesis can also be extended to the prediction of the bid premium; the worse the target was performing before, the higher the premium may be offered as the acquiring firm is able to extract greater benefits from the target firm. This notion ties to the inefficient 
management' hypothesis as the replacement of inefficient management may be the acquisition's value driver. Bugeja and Walter (1995) find evidence, albeit weak, for the recent performance hypothesis in an Australian sample. As related to takeover likelihood, the target firm's size may have an effect on the premium that is issued by the bid. Lambrecht (2004) further shows that the size of the target firm has a significant and positive on the bid premium, as larger firms incur greater transaction costs to merge.

Aspris et al. (2014) document that the pre-bid price run up is related to the toehold acquisition effect documented by Bishop (1991). The models used to measure substantial shareholder trading activity are limited as they only use a dichotomous variable to account for the existence of trading by non-acquirer substantial shareholders. Aspris et al. (2014)'s measurement of substantial shareholder trading activity may be improved by determining the purchase ratio for all substantial shareholders. Given the informed nature of substantial shareholder trades, an increase in the purchase ratio of a substantial shareholder indicates a larger premium that they try to capture (Asquith 1983). This leads to the third hypothesis:

$\mathrm{H}_{3}$ : The level of substantial shareholder purchases is positively associated with takeover bid premiums.

Aspris et al. (2014) can be extended by differentiating between different types of substantial shareholders. Given that they could hold varying levels of information, we can further test whether they explain takeover premiums on varying levels as well (Meulbroek 1992). This leads to an extension of hypothesis $\mathrm{H}_{3}$ :

$\mathrm{H}_{3 \mathrm{a}}$ : The relationship between purchases by insider shareholders and the takeover bid premium is stronger than that of other substantial shareholders.

\section{Data and Method}

Thomson Reuters SDC Platinum database was used to collect takeover bids announced between 1 January 2010 and 31 December 2013. The initial sample of bids on Australian Securities Exchange (ASX) firms with completed takeovers contained 367 takeover bids. These bid sets were then filtered by data availability on the Morningstar DatAnalysis 
Premium database. The number of firms with missing was 116 firms, resulting in a final sample of 251 firms.

Data was hand collected from 1,182 substantial shareholder notices for the 251 target and 251 individually matched control firms. Control firms were matched by industry, and size (measured by total assets). These firms were also matched to avoid duplicates; avoiding situations where the control firm was within the target set. Substantial shareholder notices were collected from the 12 months prior to the takeover bid announcement. We use Form 604: Change in Substantial Holding where these notices provide information on the change in a substantial shareholder's holdings, which can then be aggregated across longer periods into cohesive measures. The information extracted from Form 604 comprised: name of substantial holder, date on which change in holdings occurred, number of securities held prior to the notice, percentage ownership held by the holder prior to the notice, change in the number of securities held, change in percentage ownership held, dollar consideration for the change in holdings, the number of securities held after the change, and the percentage holding after the change.

Filtering of the substantial shareholder notices collected and recorded resulted in the final sample. The first step involved removing notices with unrelated firm information, repeated notices or notices involving securities other than ordinary shares. Of the number of forms removed, 16 were removed for detailing the changes in stapled securities in particular. The other step was the removal of forms which were completed poorly, including forms completed with illegible handwriting or missing information which could not be obtained through other means.

From the name of the substantial shareholder, the notices were classified into six groups according to their investor type; Financial Institution, Management, Corporation, Individual, Nominee and Other. The classification is detailed below:

- Financial Institution: Substantial shareholder is a financial institution.

- Management: Substantial shareholder is a director of the firm, as shown in the DatAnalysis database.

- Corporation: Substantial shareholder is a non-financial corporation. 
- Individual: Substantial shareholder is an individual who is not a director of the firm.

- Nominee: Substantial shareholder is a nominee entity acting on behalf of another holder.

- Other: Substantial shareholder does not meet any of the above criteria.

Data for the control variables are sourced from the Morningstar DatAnalysis Premium, SDC Platinum and DataStream.

\section{Research Method}

In analysing trading prior to bid announcements, two periods are defined: the pre-bid and the control periods. The former represents six months immediately preceding the bid announcement date and the control period is the six months immediately prior to the beginning of the pre-bid period. Anilowski Cain et al. (2009) find that takeover discussions usually occur three to five months prior to an announcement although there is variation. As such we use a pre-bid period of six months prior to the bid announcement date to capture all trades in relation to a potential bid, as in Agrawal and Nasser (2012).

We test Hypothesis 1 using a difference-in-difference (DiD) regression to test whether substantial shareholder trading in target firms differ from trading in non-target firms and whether trading in the pre-bid period is different from trading in other periods. The model is shown in Equation 1 below:

TRADES $_{i,(t-\phi, t-\vartheta)}=\alpha+61 P R E B I D_{i, t}+62$ TARGET $_{i, t}+63$ LNMCAP $_{i, t}+64$ LNPB $_{i, t}+65$ LNVOLA $_{i, t}+66$ CVOLA $_{i, t}+67$ RET $_{i}+88$ PREBID $_{i, t}{ }^{*}$ TARGET $_{i, t}+$ BSSCHEME $_{i, t}+810$ CASH $_{i, t}+811$ STOCK $_{i, t}+$ B12DRECOM $\mathrm{D}_{i, t}+\varepsilon_{i}$

where $T R A D E S_{i,(t-\phi, t-\theta)}$ represents the various trade measures, where $(\phi, \theta)=$ (12 months, 6 months) for control periods and $(\phi, \theta)=(6$ months, 0 months $)$ for prebid periods. These measures are recalculated using the dollar value of the transactions as well. PREBID $D_{i, t}$ and TARGET $T_{i, t}$ indicate whether that observation is during the pre-bid or control period, and of a target firm or control firm respectively for the ith firm. The variable of interest, $P R E B I D_{i, t} * T A R G E T_{i, t}$ is used to indicate a target firm in the pre-bid period. 
The test aims to determine whether substantial shareholders have significantly different trade measures when the PREBID $D_{i, t} * T A R G E T_{i, t}$ term is equal to one. $L N M C A P_{i, t}, L N P B_{i, t}, \quad L N V O L A_{i, t}$, CVOLA $_{i, t}$ and $R E T_{i}$ are the natural log of the firm's market capitalisation, natural log of the firm's price-to-book ratio, natural log of the firm's price volatility, change in price volatility and stock return respectively for the ith firm.

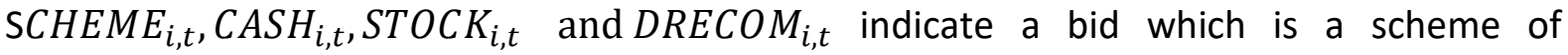
arrangement, a cash only bid, a stock only bid and an accepting director's recommendation respectively for the ith firm.

For Hypothesis 2, a logistic regression is used to determine whether substantial shareholder trades are predictive of a takeover bid. This method uses a multivariate logistic approach to determine factors predicting the occurrence of a bid, as well as calculating the rate of correct predictions.

The multivariate logistic model is estimated as follows in Equation 2:

$$
p_{i}=\frac{1}{1+\exp \left(-\left(P R_{i} \beta_{i, 0}+\sum_{j=1}^{j} X_{i, j} \beta_{i, j}\right)\right)}
$$

where $p_{i}$ represents the probability of the ith firm receiving a takeover bid, $P R_{i}$ represents the ith firm's substantial shareholder purchase ratio for the pre-bid period. The purchase ratio is a method of aggregating trades to show the aggressiveness of the substantial shareholders' trading activity. Higher purchase ratios indicate more purchases relative to sales. This measure is calculated on an aggregate of all substantial shareholder types, as well as in individual groups of financial institutions, management and corporations. $X_{i, j}$ represents the control variables. The sign of the coefficients $\beta_{i, j}$ indicates the direction of change of the odds ratio, i.e. the likelihood of a takeover bid. We also provide the rate of correct target prediction to examine our ability to predict the takeovers.

A Tobit regression is used to test Hypothesis 3 as the bid premium is not expected to be negative. The model is as follows: 


$$
\operatorname{PREM}_{i}=\left\{\begin{aligned}
P R_{i} \beta_{i, 0}+\sum_{j=1}^{j} X_{i, j} \beta_{i, j}, & P R E M_{i}>0 \\
0, & P R E M_{i} \leq 0
\end{aligned}\right.
$$

where $P R E M_{i}$ represents the bid premium for the ith target firm; $P R_{i}$ represents the ith firm's substantial shareholder purchase ratio for the pre-bid period. This measure is calculated on an aggregate group of all substantial shareholder types, as well as in subgroups of financial institutions, management and corporations. $X_{i, j}$ represents control variables. The sign of the coefficients $\beta_{i, j}$ shows the direction of change in the premium.

Descriptive statistics are presented in Table 2. Panel A of Table 2 gives an overview of the distribution of all trades, with dollar and volume measures with medians close to zero but means that deviate. The substantial variation, as shown by the standard deviations, explain the non-normality of the two data sets. As such for calculation, the trades are aggregated by period and by firm.

Panel B of Table 2 details the spread of trades in periods which are during the pre-bid period versus the control period, as well as firms which are targets versus control firms. In comparing the groups, medians are relatively close to zero throughout as expected, however the means of trades in pre-bid periods are larger than those of control periods. Interestingly, the group with the highest mean is that of the trades in a pre-bid period, in control firms, however this seems to be driven by very substantial observations. The data shows that the various groups of substantial shareholder trades appear to be quite different, and further statistical testing determines whether these differences may be explained by the hypotheses.

Panel C displays descriptive statistics detailing the distribution of target firms' characteristics. The range of the size of firms, based on assets and market capitalisation is very substantial, however the means are greater than medians, indicating the greater set of substantial firms becoming target firms. This is present throughout the characteristics, as the skewness is consistently positive.

Insert Table 2 here 
Table 3 presents the regression results used to formally test the difference in trading activity in different firms and different time periods prior to the bid. Panel A displays the results for the difference-in-difference test in explaining the trades of all substantial shareholders. The coefficients of TARGET*PREBID are significant and positive across buys, sells and net purchases, showing that all three measures increase when trading in a target firm during the pre-bid period.

Even with increases in the volume of sells, these increases are smaller than increases in the volume of buys which lead to a significant net purchase increases. These results are reflected in Panels $B$ and $D$, showing that buys, sells and net purchases by both financial institutions and corporations increased during the pre-bid period in target firms. The sign of the TARGET*PREBID variable coefficient on buys, sells and net purchases for management was also positive but not significant.

In analysing aggregate trades in Panel A, LNASSETS shows a higher level of trading in larger than smaller firms, which is most heavily reflected in the trades of institutional shareholders. Financial institutions also trade on the price-to-book ratio, however the level of buys, sells and net purchases decrease with increasing price-to-book levels. Deal characteristic variables are only significant in management trades where they explain the occurrence of a scheme, cash only or stock only deal causes management to decrease their sells.

The results show that substantial shareholders trade considerably more during pre-bid periods in target firms when compared to trading in target firms during a control period, and trading in control firms during both the pre-bid and control period. This result supports Hypothesis 1, as it is shown that on the aggregate level, substantial shareholders increase their net purchases during the pre-bid on target firms more than at other times.

The results shown in Table 2 Panel A on the aggregate measure of substantial shareholders are derived from the trading present in financial institution and corporation substantial shareholders. This implies that both groups may in fact have informational advantage and are able to predict an upcoming bid, thus trading accordingly in order to realise benefits 
from the bid. Interestingly the method of accruing shares used is to increase their buys greater than their sells, which is an active method of trading. The economic significance of this result is evident as the level of net purchases increases by $4.165^{3}$ million shares when the firm is a target and trades are during the pre-bid period.

Management substantial shareholders do not appear to significantly change their trading activity during the pre-bid period on target firms. They decrease their buys, however this is not shown to differ between the pre-bid and control period. These results are reflective of Agrawal and Nasser (2012) who find that that insiders trade passively, increasing their net purchases prior to a takeover bid. However as there is no significant increase in net purchases of management substantial shareholder in the pre-bid period in target firms, Hypothesis 1a is not supported.

Why are financial institutions and other corporations able to actively increase their holdings in a target firm prior to a bid without investigation of informed trading? A contributing factor is that the acquirer may have a toehold in the target firm and is increasing their stake in the leadup to a bid. This factor would contribute more strongly to the observed net purchase increases in corporation substantial shareholders as they are more likely to be acquirers than financial institutions.

Given that management substantial shareholders show minimal changes to their trading activity, another explanation is that the market tailors its focus of monitoring informed trading on insiders and focuses less on other substantial shareholders. As insiders, management substantial shareholders require much more rigorous disclosure and market pressure in making the decision to trade, thus reducing their ability to make profitable trades stealthily. However other substantial shareholders are not required to meet insider trading regulation or other forms of disclosure besides submitting substantial shareholder notices, and thus are more able to actively trade prior to takeover bids.

The tests conducted do not indicate, if any, the source of information these substantial shareholders are trading on. Another explanation is that substantial shareholders hold a

\footnotetext{
${ }^{3}$ Interaction term's coefficient effect calculated as $-4.397-2.648+11.21=4.165$
} 
comparative advantage in processing signals from target firms. Grossman and Stiglitz (1980) argue that a trader must benefit from a transaction made, otherwise there would be no reason to trade. In accumulating and increasing a substantial holding, a substantial shareholder's portfolio effectively becomes less diversified, and as such would not take this action if not for any possible benefits they may accrue. A substantial shareholder may use their comparative advantage, and would have greater incentive to process signals by the target firm into information on which trades could be based (Shleifer \& Vishny 1997).

Results from the logistic regression analysis are presented in Table 3. The models determine the explanatory power of substantial shareholder purchase ratios on the likelihood of a bid. The first model tests the strength of the firm specific controls used in previous literature. The results show that the inefficient management hypothesis (Manne 1965) and the growth resource mismatch factor (Palepu 1986) are slightly significant in predicting the likelihood of a bid. The coefficient for the size proxy takes a positive sign, which is not expected as larger firms have higher transaction costs of acquisition (Palepu 1986). Other variables are still within the $20 \%$ significance level, and have unexpected signs. As the samples of both time periods contain equal numbers of control and target firms, the chance prediction rate to predict a bid is $50 \%$. For the first model the model's target prediction rate is $49.39 \%$, slightly lower than chance, indicating that the variables used introduce a level of noise into the model.

Insert Table 3 here

The first model to include the substantial shareholder trade purchase ratios uses the aggregate measure; the purchase ratio of all substantial shareholders in the pre-bid period is a significant predictor of the likelihood of a takeover bid. The sign of the coefficient indicates that as the purchase ratio of substantial shareholders increase, the likelihood of takeover increases as expected.

The control variables have the same signs as the previous model, with ROE and the sales growth to liquidity ratio maintaining significance after the addition of the purchase ratio to the model. Other control variables do not show great significance in explaining the 
likelihood of the bid. The fit of the model also increases from a McFadden's R-squared of 0.014 to 0.027 with the addition of the purchase ratio to the model. Overall, including the purchase ratio into the takeover likelihood model increases its fit and prediction rate which shows that the model has been improved.

When examining the individual groups of substantial shareholders, we find that again the corporation and financial institution groups provide strong evidence of increasing the likelihood of takeover, while management substantial shareholders have no significant effect. Furthermore the target prediction rates and McFadden R-squared values of both models including financial institution and corporation purchase ratios improve, which adding management purchase ratios does not improve the models greatly. The control variables for these models maintain their signs and do not differ greatly in levels of significance.

Given a positive sign on the purchase ratio, substantial shareholders buying is a sign that a takeover is likely to occur. This result supports Hypothesis 2; the substantial shareholders purchase ratio is positively related to the likelihood of a bid. The target prediction rate of this model is much higher; by adding the substantial shareholder purchase ratio to the previous model, the target prediction rate increases from 49.4 to $58.5 \%$. This shows that not only does the odds ratio of the likelihood of takeover increase when substantial shareholders increasing their buys relative to sells, but the overall model increases accuracy. This supports Brockman and Yan (2009) who find that in the US, the existence of block holders increase the probability of informed trading. The ability of substantial shareholder trades to signal an incoming takeover indicates the level of information they hold. The results from individual groups of substantial shareholders show that financial institution and corporation substantial shareholders' purchase ratios provide stronger explanatory power than those of management substantial shareholder purchase ratios. In summary the results of these tests provide a strong argument that the purchase ratios of substantial shareholder trading calculated during the pre-bid period are significantly and positively correlated to the likelihood of a bid and they increase the accuracy of the model. 
To further examine substantial shareholder informational advantage, we use a Tobit model to address whether substantial shareholders' purchase ratios in the pre-bid period are able to predict the bid premium associated with an incoming bid (Hypothesis 3). We also examine the effects of different types of substantial shareholder purchase ratios on the bid premium. Table 4 displays results of the Tobit analysis conducted on the subsample of target firms with bids. In general, the results show that substantial shareholder purchase ratios have an insignificant effect on the bid premium. Across panels $A, B$ and $C$, different measures of premium are used; namely the bid premium relative to the previous day's price (PREM1), the previous week's price (PREM7) and previous month's price (PREM30). We find that almost all measures of substantial shareholders' purchase ratios are not significantly related to the bid premium. Only financial institutions' purchase ratios are significantly related to the premium based on the previous day's price.

Insert Table 4 here

When testing PREM1 and PREM7, all purchase ratio coefficients have a negative sign, indicating a negative relationship between substantial shareholders' purchase ratios and the premium measured. This implies that substantial shareholders increase their sells, relative to buys, when the bid will have a higher premium. The signs of the purchase ratio coefficients are mixed when testing PREM30, however these coefficients show very little significance. The level of significance of the net purchases measure in general decreased as the lag between the bid date and the date used to find the base price increased.

Control variables used in the models show some significance, consistent across models when examining particular measures of bid premium. In Panel $A$, the growth resource mismatch measure GROWSC is significant and positive, indicating that a higher premium is placed on high growth, low resource firms. In both Panels B and C the price-to-book measure is significant, but negative indicating that firms with a higher price-to-book ratio are receiving a higher premium. EBIT growth and return on equity are significant in the PREM7 and PREM30 model sets respectively, and both negatively related, indicating that firms with poorer growth prospects and performance receive lower premiums. Of the deal characteristic variables included, stock only deals were significant and negatively related to 
the bid premium, when examined against PREM1, but the level of significance decreased as more lagged base prices were used to calculate the premium.

Due to the peculiar results found, we conduct a subsample analysis of high and low premium target firms, split into high and low subsamples by the mean. Given the significance found in financial institution substantial shareholder purchase ratios, we conduct a subsample analysis on both the aggregate and financial institution substantial shareholder purchase ratio measures.

Insert Table 5 here

Table 5 displays results for the subsample analysis. The purchase ratios of both aggregate and financial institution substantial shareholders are not significantly related to the premium calculated using all three different measures of premium. When split into high and low premium subsamples, we do not find different signs between high and low premium sets in aggregate as both are positive. In financial institution substantial shareholders, the high premium sets have a negative sign and low premium a positive sign, however these coefficients are highly insignificant.

Theoretically a substantial shareholder would attempt to increase their holdings in order to obtain greater benefits from the bid premium. However, the results do not support this theory. We find that purchase ratios are negatively related to the bid premium, albeit not significantly. This suggests a few different possible explanations. Substantial shareholders may trade stealthily in order to achieve profits. Bris (2005) examines insider trading around acquisitions in 52 countries under various insider trading laws, finding that insider trading law enforcement increases the incidence and profitability of insider trading. The results presented in Table 4 may allude to this; substantial shareholders may choose to increase their holdings if they know that a bid's premium will not be very substantial in order to avoid suspicion. Further evidence for this theory is that financial institution substantial shareholders are the only group where there is a significant relationship. Rumours surrounding a bid with a larger premium may cause substantial shareholders, particularly financial institutions, to trade more cautiously so as to avoid suspicion of insider trading. 
Another explanation is that substantial shareholders do not have ex ante information about the bid premium, only about the existence of an incoming bid. This means that their trades are able to signal the incoming bid but they do not increase their buys in order to capture a higher premium as they do not know what the premium of the bid will be. Overall we do not find evidence to support Hypothesis 3; substantial shareholders' purchase ratios do not have a positive relationship with the bid premium. Nor do we find support for Hypothesis $3 a$ as management substantial shareholders' purchase ratios are not more strongly related to the bid premium than other groups.

Subsample analysis between high and low premium deals further supports the latter explanation; aggregate substantial shareholders' purchase ratios do not negatively relate to high premiums. Financial institution purchase ratios are negatively related to premium, but at a weak significance level. This shows that the more likely explanation for the relationship between substantial shareholder purchase ratios and the bid premium is that substantial shareholders do not hold information about the bid's premium.

\section{Summary and conclusions}

Substantial shareholders are widely assumed to have informational advantage over other shareholders, potentially through a comparative advantage in collecting and processing information or privileged management consultation. This premise is implicit in legislation that requires holders of five per cent or more of a company's ordinary voting rights to disclose and report changes in their holdings. We examine whether substantial shareholders' assumed informational advantage manifests in the pre-bid trading behaviour of target substantial shareholders as they seek to increase their profit from the premium typically offered in a takeover bid. We test whether aggregated substantial shareholders in 251 Australian Stock Exchange (ASX) target firms traded differently to 251 matched control firms, controlling for substantial shareholders' normal trading by comparing their trading immediately prior to a bid to a control period before the bid. We find evidence that target substantial shareholders make greater net purchases than control firm substantial shareholders prior to a bid. 
We also test whether substantial shareholders' trades were predictive of the likelihood of a bid, and bid characteristics including the premium. We find that substantial shareholder trades significantly improve the accuracy of bid prediction models, although there is no evidence that substantial shareholders are able to predict the bid premium, or other deal characteristics such as the method of payment. These findings are robust to changes in the measure of substantial shareholder trading activity. All tests are conducted using an aggregate of all types of substantial shareholders, as well as separate types of substantial shareholders in order to test whether a particular subset of substantial shareholders has more explanatory power than others. Interestingly, we find that insiders (management) have the least explanatory power, when compared to financial institutions or other corporations' trades. While substantial shareholders may have an informational advantage, they may not all act on this information.

These findings suggest a few things; first, in general substantial shareholders hold an informational advantage regarding future takeover activity. Substantial shareholders increase their net purchases and trade more aggressively prior to a bid. Second, more accurate prediction of the likelihood of a bid may be the extent of substantial shareholders' informational advantage. We infer that substantial shareholders either do not have or do not exploit information about the terms or details of the deal as their aggregated trades are not significant predictors of the bid premium or other deal characteristics. Finally, the findings indicate that management insiders do not have the most informative trades. A possible explanation is that insider trading regulation means that managers' trades are subject to heavier market scrutiny and require more stringent disclosure in trading, restricting them from acting on private information. Other substantial shareholders are under less scrutiny from the market and regulatory bodies and thus more easily able to trade on their superior information. Another explanation is that the ability to predict takeover bids is a result of a comparative advantage held by substantial shareholders. As substantial shareholders by definition are less diversified than minority shareholders, their superior returns around a takeover bid may be part of their compensation for accepting the diversifiable risk and more closely monitor managers. 
While the manually collected data set of substantial shareholder trades has benefits in its direct usage in this study, there are limitations to the information collected. First, as this study only deals with Form 604: Change in Substantial Holdings, we do not record instances of Form 603: Becoming a substantial holder and Form 605: Ceasing to be a substantial holder. As such a holder of $10 \%$ may decrease their holdings by $5.01 \%$ to $4.99 \%$, which would not be accounted for. While the exact change in holdings would not be discernible from the 603 or 605 forms, it is still an information source about substantial shareholder trading that has not been exploited. Following from this, only movements of $1 \%$ or greater are recorded. A substantial shareholder may own $5 \%$ of a company and subsequently increase their holdings to $5.99 \%$ which would not be reported. As such the data is likely to have a downward bias which limits its ability to reflect true substantial shareholder trading activity.

The second limitation is related to the timing of substantial shareholder trades. As a substantial shareholder is only required to report their change in holdings once they reach the $1 \%$ change threshold, the timing of the change in holdings is unclear. For example a substantial shareholder holding $7 \%$ ownership may increase their holdings by $0.99 \%$ prior to the bid without reporting their trade, then increase by a further $0.01 \%$ after the bid announcement, at which they will report a $1 \%$ change occurring on the date after the bid announcement. Trading activity such as this would not be represented in this data set as the notices recorded were only those that were reported up until the bid announcement date. This is particularly important for firms of substantial market capitalisation in which even a $0.5 \%$ increase holdings is a substantial absolute investment.

Studies examining substantial shareholders and their role in the market are sparse, leaving much scope for future research to examine different signals of their trading activity, whether prior to informational events or through regular trading periods. For example future research could study whether substantial shareholders hold a continuous informational advantage by examining the relationship between their trades and the time series of stock returns. Such research would complement this study in further discerning the extent of the supposed informational advantage substantial shareholders hold and the signals their trades could provide to the market. 
Another potential area for future research is to examine the extent to which returns are affected by insider trading and substantial shareholder trading; in particular management substantial shareholders. Having found that management substantial shareholders' trades provide little explanatory power in the predicting upcoming takeovers, perhaps a more granular approach is required, which could incorporate substantial shareholder notices with insider trading disclosures. A combined database with this information could provide further insight into the trading behaviour of investors who potentially hold superior information, and their effect on the market. 


\section{References}

Admati, A.R., Pfleiderer, P., 2009. The "wall street walk" and shareholder activism: Exit as a form of voice. Review of Financial Studies, 2645-2685

Agrawal, A., Nasser, T., 2012. Insider trading in takeover targets. Journal of Corporate Finance 18, 598-625

Ambrose, B.W., Megginson, W.L., 1992. The role of asset structure, ownership structure, and takeover defenses in determining acquisition likelihood. Journal of Financial and Quantitative Analysis 27, 575-589

Anilowski Cain, C., Macias, A.J., Sanchez, J.M., 2009. Can targets benefit from negotiations? Evidence from auctions and negotiations. Evidence from Auctions and Negotiations (November 18, 2009)

ASIC, 2013. Regulartory Guide 5: Relevant interests and substantial holding notices. (ASIC) ASaIC (Ed.), pp. 27-32

Aspris, A., Foley, S., Frino, A., 2014. Does insider trading explain price run-up ahead of takeover announcements? Accounting \& Finance 54, 25-45

Asquith, P., 1983. Merger bids, uncertainty, and stockholder returns. Journal of Financial Economics 11, 51-83

Barnes, P., 1999. Predicting UK takeover targets: some methodological issues and an empirical study. Review of Quantitative Finance and Accounting 12, 283-302

Belkaoui, A., 1978. Financial ratios as predictors of Canadian takeovers. Journal of Business Finance \& Accounting 5, 93-107

Bharath, S.T., Jayaraman, S., Nagar, V., 2013. Exit as governance: An empirical analysis. The Journal of Finance 68, 2515-2547

Bishop, S.R., 1991. Pre-bid acquisitions and substantial shareholder notices. Australian Journal of Management 16, 1-33

Bris, A., 2005. Do insider trading laws work? European Financial Management 11, 267-312

Brockman, P., Yan, X.S., 2009. Block ownership and firm-specific information. Journal of Banking \& Finance 33, 308-316

Brown, D.T., Ryngaert, M.D., 1991. The mode of acquisition in takeovers: Taxes and asymmetric information. Journal of Finance, 653-669

Bugeja, M., da Silva Rosa, R., 2008. Taxation of shareholder capital gains and the choice of payment method in takeovers. Accounting and Business Research 38, 331-350

Bugeja, M., da Silva Rosa, R., Izan, H., Ngan, S., 2015. To scheme or bid? Choice of takeover method and impact on premium. Australian Journal of Management, 1-32

Bugeja, M., Walter, T., 1995. An empirical analysis of some determinants of the target shareholder premium in takeovers. Accounting \& Finance 35, 33-60

Bushee, B.J., 1998. The influence of institutional investors on myopic R\&D investment behavior. Accounting review, 305-333

Bushee, B.J., Goodman, T.H., 2007. Which institutional investors trade based on private information about earnings and returns? Journal of Accounting Research 45, 289-321

Chakravarty, S., 2001. Stealth-trading: Which traders' trades move stock prices? Journal of Financial Economics 61, 289-307

da Silva Rosa, R., Izan, H., Shan, J., 2006. Market misvaluation driven acquisitions: Contrary Australian evidence. Company and Securities Law Journal 24, 75-92

Edmans, A., 2009. Blockholder trading, market efficiency, and managerial myopia. The Journal of Finance 64, 2481-2513

Fama, E.F., 1980. Agency problems and the theory of the firm. The journal of political economy, 288307 
Gallagher, D.R., Gardner, P.A., Swan, P.L., 2013. Governance through trading: Institutional swing trades and subsequent firm performance. Journal of Financial and Quantitative Analysis 48, 427-458

Gort, M., 1969. An economic disturbance theory of mergers. The Quarterly Journal of Economics, 624-642

Grossman, S.J., Stiglitz, J.E., 1980. On the impossibility of informationally efficient markets. The American economic review, 393-408

Hayward, M.L., Hambrick, D.C., 1997. Explaining the premiums paid for substantial acquisitions: Evidence of CEO hubris. Administrative Science Quarterly, 103-127

Heflin, F., Shaw, K.W., 2001. Adverse selection, inventory-holding costs, and depth. Journal of Financial Research 24, 65-82

Holderness, C.G., 2003. A survey of blockholders and corporate control. Economic policy review 9-23

Jensen, M.C., 1986. Agency cost of free cash flow, corporate finance, and takeovers. Corporate Finance, and Takeovers. American Economic Review 76-91

Keown, A.J., Pinkerton, J.M., 1981. Merger announcements and insider trading activity: An empirical investigation. The journal of finance $36,855-869$

Laamanen, T., 2007. On the role of acquisition premium in acquisition research. Strategic Management Journal 28, 1359-1369

Lambrecht, B.M., 2004. The timing and terms of mergers motivated by economies of scale. Journal of Financial Economics 72, 41-62

Manne, H.G., 1965. Mergers and the market for corporate control. The Journal of Political Economy, 110-120

Manski, C.F., McFadden, D., 1981. Structural analysis of discrete data with econometric applications. Mit Press Cambridge, MA.

McKinnon, J.L., Dalimunthe, L., 1993. Voluntary disclosure of segment information by Australian diversified companies. Accounting \& Finance 33, 33-50

Meulbroek, L.K., 1992. An empirical analysis of illegal insider trading. The Journal of Finance 47, 1661-1699

Myers, S.C., 1984. The capital structure puzzle. The journal of finance 39, 574-592

Palepu, K.G., 1986. Predicting takeover targets: A methodological and empirical analysis. Journal of Accounting and Economics 8, 3-35

Piotroski, J.D., Roulstone, D.T., 2005. Do insider trades reflect both contrarian beliefs and superior knowledge about future cash flow realizations? Journal of Accounting and Economics 39, 55 81

Powell, R.G., 1997. Modelling takeover likelihood. Journal of Business Finance \& Accounting 24, 1009-1030

Powell, R.G., 2001. Takeover prediction and portfolio performance: a note. Journal of Business Finance \& Accounting 28, 993-1011

Rodrigues, B.D., Stevenson, M.J., 2013. Takeover prediction using forecast combinations. International Journal of Forecasting 29, 628-641

Shleifer, A., Vishny, R.W., 1997. A survey of corporate governance. Journal of Finance 52, 737-783

Stevens, D.L., 1973. Financial characteristics of merged firms: A multivariate analysis. Journal of Financial and Quantitative Analysis 8, 149-158

Zeckhauser, R.J., Pound, J., 1990. Are substantial shareholders effective monitors? An investigation of share ownership and corporate performance. In: Asymmetric information, corporate finance, and investment. University of Chicago Press, pp. 149-180.

Zhang, W., Cahan, S.F., Allen, A.C., 2005. Insider trading and pay-performance sensitivity: An empirical analysis. Journal of Business Finance \& Accounting 32, 1887-1919 


\section{Table 1: Substantial Shareholder Trade Descriptive Statistics}

Table 1 displays descriptive statistics for the sample of substantial shareholder trades. Panel A displays descriptive statistics of all trades from different firms and time periods. Positive values indicate purchases while negative values indicate sales. Dollar, in Millions is the dollar value of the overall trade in millions of dollars. Volume, in Millions is the number of shares in the overall trade in millions of shares. Panel B displays descriptive statistics of both Dollar and Volume in Millions of units, arranged in subsamples depending on whether the notice is submitted during the pre-bid or control period and whether the notice is submitted under a target firm or control firm. Panel C displays descriptive statistics of the set of 251 target firms. Assets and MarketCap are reported in millions of dollars. PB is the price-to-book ratio, VOLA is the firm's price volatility prior to the bid, CVOLA is the firm's change in price volatility across periods, RET is the firm's average daily price return, ROE is the firm's return on equity, GROWEBIT is the firm's EBIT growth over the past year, NETINTCOV is the firms net interest cover reported in thousands, and GROWSC is the sales growth to current ratio. Detailed descriptions of these characteristics are available in Table 4.

\begin{tabular}{lrrrrrrrr}
\hline Panel A: Total Trades & $N$ & Mean & Median & Std. Dev. & Min. & Max. & Skew. & Kurt. \\
\hline & & & & & & & & \\
Dollar, in Millions & 1182 & 49.213 & 0.894 & 1104.553 & -266.871 & 33405.680 & 27.000 & 764.551 \\
Volume, in Millions & 1182 & 6.777 & 1.627 & 120.193 & -2335.035 & 2927.883 & 6.228 & 420.429
\end{tabular}

\section{Panel B: By Period, Firm}

Trades in pre-bid periods, in target firms

$\begin{array}{lrrrrrrrr}\text { Dollar, in Millions } & 584 & 35.365 & 1.030 & 749.320 & -206.278 & 18093.520 & 24.029 & 579.563 \\ \text { Volume, in Millions } & 584 & 3.882 & 2.160 & 31.601 & -274.417 & 233.000 & -1.235 & 36.744\end{array}$

Trades in pre-bid periods, in control firms

\begin{tabular}{lrrrrrrrr}
\hline Dollar, in Millions & 217 & 162.028 & 0.868 & 2267.690 & -95.043 & 33405.680 & 14.619 & 214.809 \\
Volume, in Millions & 217 & -7.334 & 1.125 & 167.396 & -2335.035 & 294.000 & -12.590 & 174.511
\end{tabular}

Trades in control periods, in target firms

$\begin{array}{llllllrrr}\text { Dollar, in Millions } & 161 & 4.544 & 0.236 & 21.845 & -62.055 & 172.185 & 3.647 & 26.943 \\ \text { Volume, in Millions } & 161 & 2.968 & 0.630 & 13.981 & -63.060 & 82.830 & 2.325 & 19.580\end{array}$

Trades in control periods, in control firms

\begin{tabular}{lrrrrrrrr} 
Dollar, in Millions & 220 & 7.610 & 1.176 & 38.476 & -266.871 & 230.161 & 0.957 & 26.285 \\
Volume, in Millions & 220 & 31.182 & 1.594 & 215.958 & -253.906 & 2927.883 & 11.371 & 149.410 \\
\hline Panel C: Target & & & & & & & & \\
\hline Assets ('000 000s) & 251 & 881.180 & 111.010 & 2299.158 & 0.004 & 20858.000 & 5.188 & 36.598 \\
MarketCap ('000 000s) & 251 & 573.140 & 67.927 & 1482.565 & 0.746 & 11720.550 & 4.791 & 30.020 \\
PB & 251 & 1.637 & 1.040 & 1.868 & -0.170 & 9.680 & 2.729 & 11.175 \\
VOLA & 251 & 0.189 & 0.044 & 0.748 & 0.000 & 8.040 & 9.399 & 97.674 \\
CVOLA & 251 & 0.017 & 0.000 & 0.217 & -1.756 & 1.718 & 2.227 & 50.732 \\
RET & 251 & 0.001 & 0.001 & 0.004 & -0.012 & 0.023 & 1.475 & 9.149 \\
ROE & 251 & 0.201 & 0.019 & 3.756 & -4.933 & 56.651 & 13.721 & 205.257 \\
GROWEBIT & 251 & 2.023 & 0.283 & 14.806 & -0.965 & 230.711 & 14.803 & 228.602 \\
NETINTCOV ('000s) & 251 & -801.773 & -0.002 & 8392.937 & -60900 & 94700 & 0.004 & 0.081 \\
GROWSC & 251 & 23.716 & 0.068 & 193.242 & -27.085 & 2201.666 & 10.396 & 112.687 \\
\hline
\end{tabular}




\section{Table 2: Difference-in-Difference Regressions for Trading Activity Prior to Bids using Volume}

This table shows the results from a combination of multivariate regressions conducted to test the differences in trading activity in target and control firms in pre-bid and control time periods. The regressions use a set of 251 target firms and 251 control firms that were listed on the ASX during the period 1/1/2010-31/12/2013. The dependent variable used for the particular model is displayed at the top of each set of results; the prefix A indicates a measure of all substantial shareholder trading, $\mathrm{F}$ indicates an aggregate of financial institution substantial shareholders, $\mathrm{M}$ indicates an aggregate of management substantial shareholders and $\mathrm{C}$ indicates an aggregate of corporation substantial shareholders, while the suffix BUY indicates that the variable is an aggregate of substantial shareholder buys across the period, SELL indicates that the variable is an aggregate of substantial shareholder buys across the period and NET indicates that the variable is an aggregate of substantial shareholder buys minus sells across the period, all elements winsorised at the $1 \%$ level. TARGET indicates when the firm is a target or control firm. PREBID indicates when the observation is during the pre-bid period or the control period. TARGET*PREBID is an interaction between both TARGET and PREBID. LNVOLA is the $\log$ stock price volatility. CVOLA is the change in volatility between periods. RET is the average stock return for the prior period. LNPB is the log of the firm's price-to-book ratio. LNASSETS is the log of the firm's total asset value. SCHEME indicates if the deal is a Scheme of Arrangement. CASH indicates a cash only bid. STOCK indicates a stock only deal. DRECOM indicates an accept response by director recommendation. Test statistics include relevant $p$-values (two-tailed) from robust standard errors. $*, * *$ and $* * *$ denote significance levels of $10 \%, 5 \%$ and $1 \%$ respectively.

\begin{tabular}{|c|c|c|c|c|c|c|}
\hline \multirow[b]{2}{*}{ Variable } & \multicolumn{2}{|c|}{ ABUY } & \multicolumn{2}{|c|}{ ASELL } & \multicolumn{2}{|c|}{ ANET } \\
\hline & Coef. & p. value & Coef. & p. value & Coef. & p. value \\
\hline \multicolumn{7}{|l|}{ Panel A: Aggregate } \\
\hline TARGET & -5.178 & 0.1209 & -0.632 & 0.7158 & -4.397 & 0.1337 \\
\hline PREBID & -1.912 & 0.5161 & -0.444 & 0.7542 & -2.648 & 0.3025 \\
\hline TARGET*PREBID & $15.430 * * *$ & 0.0001 & $5.612^{* * *}$ & 0.0038 & $11.210 * * *$ & 0.0011 \\
\hline LNVOLA & 0.068 & 0.5296 & 0.059 & 0.2776 & 0.034 & 0.7124 \\
\hline CVOLA & 1.143 & 0.7882 & -0.545 & 0.6487 & 1.103 & 0.7653 \\
\hline RET & -42.420 & 0.8574 & 14.040 & 0.8882 & -164.000 & 0.3501 \\
\hline LNPB & -0.581 & 0.1523 & $-0.523 * * *$ & 0.0091 & -0.170 & 0.6411 \\
\hline LNASSETS & $2.216^{* * *}$ & 0.0001 & $1.331 * * *$ & 0.0000 & $1.076^{* *}$ & 0.0253 \\
\hline SCHEME & -1.087 & 0.7395 & -2.052 & 0.1190 & 0.764 & 0.7989 \\
\hline $\mathrm{CASH}$ & -2.083 & 0.5365 & -2.044 & 0.3146 & -0.596 & 0.8432 \\
\hline STOCK & -0.776 & 0.8599 & -1.385 & 0.5147 & -0.251 & 0.9490 \\
\hline DRECOM & 0.522 & 0.8373 & 1.065 & 0.5961 & -0.692 & 0.7791 \\
\hline Industry Fixed Effects & YES & & YES & & YES & \\
\hline Year Fixed Effects & YES & & YES & & YES & \\
\hline Constant & $-27.320 * * *$ & 0.0044 & $-18.790 * * *$ & 0.0000 & -11.730 & 0.1421 \\
\hline Adj. R-squared & 0.030 & & 0.038 & & 0.002 & \\
\hline N. of cases & 956 & & 956 & & 956 & \\
\hline
\end{tabular}




\begin{tabular}{|c|c|c|c|c|c|c|}
\hline \multirow[b]{2}{*}{ Variable } & \multicolumn{2}{|c|}{ FBUY } & \multicolumn{2}{|c|}{ FSELL } & \multicolumn{2}{|c|}{ FNET } \\
\hline & Coef. & p. value & Coef. & p. value & Coef. & p. value \\
\hline \multicolumn{7}{|l|}{ Panel B: Fin. Institution } \\
\hline TARGET & $-4.033^{*}$ & 0.0981 & -0.775 & 0.4671 & -3.408 & 0.1327 \\
\hline PREBID & -1.963 & 0.3247 & -0.100 & 0.9047 & -2.414 & 0.2076 \\
\hline TARGET*PREBID & $10.570 * * *$ & 0.0001 & $3.351 * * *$ & 0.0057 & $7.498 * * *$ & 0.0024 \\
\hline LNVOLA & 0.033 & 0.7014 & 0.034 & 0.2916 & 0.022 & 0.7832 \\
\hline CVOLA & 0.844 & 0.8337 & -0.416 & 0.6546 & 1.193 & 0.7282 \\
\hline RET & -12.450 & 0.9378 & 0.766 & 0.9888 & -77.490 & 0.5526 \\
\hline LNPB & $-0.835 * * *$ & 0.0046 & $-0.314 * *$ & 0.0120 & $-0.480^{*}$ & 0.0755 \\
\hline LNASSETS & $2.114^{* * *}$ & 0.0000 & $1.051^{* * *}$ & 0.0000 & $1.183^{* * *}$ & 0.0015 \\
\hline SCHEME & -1.807 & 0.3672 & -0.669 & 0.5317 & -0.324 & 0.8601 \\
\hline CASH & -0.109 & 0.9652 & -0.204 & 0.8727 & -0.437 & 0.8419 \\
\hline STOCK & -0.059 & 0.9813 & 0.124 & 0.9213 & -0.907 & 0.6928 \\
\hline DRECOM & 0.078 & 0.9648 & -0.461 & 0.6284 & 0.354 & 0.8100 \\
\hline Industry Fixed Effects & YES & & YES & & YES & \\
\hline Year Fixed Effects & YES & & YES & & YES & \\
\hline Constant & $-29.970 * * *$ & 0.0000 & $-15.820 * * *$ & 0.0000 & $-16.170 * * *$ & 0.0069 \\
\hline Adj. R-squared & 0.048 & & 0.050 & & 0.009 & \\
\hline \multirow[t]{3}{*}{ N. of cases } & 956 & & 956 & & 956 & \\
\hline & \multicolumn{2}{|c|}{ MBUY } & \multicolumn{2}{|c|}{ MSELL } & \multicolumn{2}{|c|}{ MNET } \\
\hline & Coef. & p. value & Coef. & p. value & Coef. & p. value \\
\hline \multicolumn{7}{|l|}{ Panel C: Management } \\
\hline TARGET & $-0.053^{*}$ & 0.0749 & 0.013 & 0.1153 & $-0.063 * *$ & 0.0403 \\
\hline PREBID & 0.062 & 0.1283 & 0.000 & 1.0000 & 0.056 & 0.1578 \\
\hline TARGET*PREBID & 0.003 & 0.9602 & 0.010 & 0.1277 & -0.002 & 0.9756 \\
\hline LNVOLA & 0.001 & 0.4186 & -0.001 & 0.4138 & 0.001 & 0.4491 \\
\hline CVOLA & 0.030 & 0.2312 & 0.002 & 0.5833 & 0.028 & 0.2836 \\
\hline RET & 1.450 & 0.6060 & -0.363 & 0.1267 & 2.243 & 0.4262 \\
\hline LNPB & -0.003 & 0.6154 & 0.001 & 0.2922 & -0.002 & 0.7289 \\
\hline LNASSETS & $-0.018 * *$ & 0.0446 & -0.000 & 0.6298 & $-0.016^{*}$ & 0.0791 \\
\hline SCHEME & 0.007 & 0.8813 & $-0.007 * *$ & 0.0116 & 0.015 & 0.7482 \\
\hline CASH & 0.048 & 0.2145 & $-0.017^{* *}$ & 0.0449 & $0.067^{*}$ & 0.0880 \\
\hline STOCK & 0.070 & 0.2813 & $-0.020 * *$ & 0.0199 & 0.087 & 0.1830 \\
\hline DRECOM & 0.035 & 0.5408 & 0.001 & 0.9365 & 0.035 & 0.5443 \\
\hline Industry Fixed Effects & YES & & YES & & YES & \\
\hline Year Fixed Effects & YES & & YES & & YES & \\
\hline Constant & $0.326 *$ & 0.0556 & 0.006 & 0.6545 & $0.283^{*}$ & 0.0920 \\
\hline Adj. R-squared & 0.006 & & 0.024 & & 0.005 & \\
\hline N. of cases & 956 & & 956 & & 956 & \\
\hline
\end{tabular}




\begin{tabular}{|c|c|c|c|c|c|c|}
\hline & \multicolumn{2}{|c|}{ CBUY } & \multicolumn{2}{|c|}{ CSELL } & \multicolumn{2}{|c|}{ CNET } \\
\hline & Coef. & p. value & Coef. & p. value & Coef. & p. value \\
\hline \multicolumn{7}{|l|}{ Panel D: Corporation } \\
\hline TARGET & 0.632 & 0.4717 & 0.052 & 0.7147 & 0.731 & 0.4062 \\
\hline PREBID & -0.270 & 0.5562 & -0.079 & 0.3500 & -0.278 & 0.5292 \\
\hline TARGET*PREBID & $2.845^{* * *}$ & 0.0010 & $0.233 *$ & 0.0883 & $2.668 * * *$ & 0.0017 \\
\hline LNVOLA & 0.005 & 0.8550 & 0.005 & 0.2208 & 0.001 & 0.9639 \\
\hline CVOLA & -0.500 & 0.2677 & -0.068 & 0.3714 & -0.461 & 0.2924 \\
\hline RET & $-60.450 *$ & 0.0662 & -6.491 & 0.2533 & $-57.230 *$ & 0.0791 \\
\hline LNPB & 0.021 & 0.8517 & $-0.032 *$ & 0.0588 & 0.041 & 0.7200 \\
\hline LNASSETS & 0.017 & 0.8633 & -0.001 & 0.9150 & 0.015 & 0.8780 \\
\hline SCHEME & -1.118 & 0.1461 & $-0.173 *$ & 0.0548 & -1.007 & 0.1882 \\
\hline CASH & -0.837 & 0.3355 & -0.097 & 0.4733 & -0.938 & 0.2787 \\
\hline STOCK & -0.472 & 0.6831 & -0.128 & 0.4134 & -0.470 & 0.6841 \\
\hline DRECOM & -0.080 & 0.9161 & 0.036 & 0.7588 & -0.068 & 0.9287 \\
\hline Industry Fixed Effects & YES & & YES & & YES & \\
\hline Year Fixed Effects & YES & & YES & & YES & \\
\hline Constant & 0.524 & 0.7384 & 0.211 & 0.2577 & 0.490 & 0.7520 \\
\hline Adj. R-squared & 0.028 & & 0.007 & & 0.027 & \\
\hline N. of cases & 956 & & 956 & & 956 & \\
\hline
\end{tabular}


Table 3: Logistic Regression using Purchase Ratio

This table presents the results of the logit regressions conducted to test the effect of substantial shareholder purchase ratios on the likelihood of a bid. The regressions use a set of 251 target firms and 251 control firms that were listed on the ASX during the period 1/1/2010-31/12/2013. The dependent variable is BID, indicating whether the firm is a target firm and has a bid, or a control firm without a bid. PURCHASERATIO is the purchase ratio of the particular category of substantial shareholders, as indicated for the model, winsorised at the $1 \%$ level. ROE is the return on equity for the firm. GROWEBIT is the firm's one year EBIT growth. LNPB is the log of the firm's price-to-book ratio. GROWSC is the ratio of the firm's one year operating revenue growth to the current ratio. NETINTCOV is the firm's net interest cover. LNASSETS is the log of the firm's total assets. Test statistics include relevant p-values (two-tailed) from robust standard errors, the Log Likelihood, McFadden R-Squared, the model's Correct Prediction Rate and Chance Prediction rate. *,* and *** denote significance levels of $10 \%, 5 \%$ and $1 \%$ respectively.

\begin{tabular}{|c|c|c|c|c|c|c|c|c|c|c|}
\hline & \multicolumn{2}{|c|}{ No Trades } & \multicolumn{2}{|c|}{ Aggregate } & \multicolumn{2}{|c|}{ Fin. Institution } & \multicolumn{2}{|c|}{ Management } & \multicolumn{2}{|c|}{ Corporation } \\
\hline & Coef. & Std. Err. & Coef. & Std. Err. & Coef. & Std. Err. & Coef. & Std. Err. & Coef. & Std. Err. \\
\hline PURCHASERATIO & & & $\begin{array}{c}0.670 * * * \\
(0.0031)\end{array}$ & 0.227 & $\begin{array}{c}0.604 * * \\
(0.0138)\end{array}$ & 0.245 & $\begin{array}{c}0.269 \\
(0.6669)\end{array}$ & 0.625 & $\begin{array}{l}1.220 * * * \\
(0.0007)\end{array}$ & 0.359 \\
\hline ROE & $\begin{array}{c}0.018 * * \\
(0.0131)\end{array}$ & 0.007 & $\begin{array}{c}0.019 * \\
(0.0813)\end{array}$ & 0.011 & $\begin{array}{c}0.019 * * \\
(0.0297)\end{array}$ & 0.009 & $\begin{array}{c}0.018 * * \\
(0.0126)\end{array}$ & 0.007 & $\begin{array}{l}0.023 \\
(0.3813)\end{array}$ & 0.026 \\
\hline GROWEBIT & $\begin{array}{c}0.015 \\
(0.2061)\end{array}$ & 0.012 & $\begin{array}{c}0.015 \\
(0.1387)\end{array}$ & 0.010 & $\begin{array}{c}0.017 \\
(0.2222)\end{array}$ & 0.014 & $\begin{array}{c}0.014 \\
(0.1819)\end{array}$ & 0.011 & $\begin{array}{l}0.012 \\
(0.1042)\end{array}$ & 0.007 \\
\hline LNPB & $\begin{array}{c}0.057 \\
(0.3678)\end{array}$ & 0.063 & $\begin{array}{c}0.056 \\
(0.3781)\end{array}$ & 0.063 & $\begin{array}{c}0.055 \\
(0.3849)\end{array}$ & 0.064 & $\begin{array}{c}0.058 \\
(0.3559)\end{array}$ & 0.063 & $\begin{array}{c}0.057 \\
(0.3676)\end{array}$ & 0.063 \\
\hline GROWSC & $\begin{array}{l}-0.002 * \\
(0.0904)\end{array}$ & 0.001 & $\begin{array}{l}-0.001 * \\
(0.0751)\end{array}$ & 0.001 & $\begin{array}{l}-0.001 \\
(0.1027)\end{array}$ & 0.001 & $\begin{array}{l}-0.002 * \\
(0.0908)\end{array}$ & 0.001 & $\begin{array}{l}-0.002 * * \\
(0.0344)\end{array}$ & 0.001 \\
\hline NETINTCOV & $\begin{array}{l}-1.12 E-08 \\
(0.1642)\end{array}$ & 8.03E-09 & $\begin{array}{l}-9.14 \mathrm{E}-09 \\
(0.1979)\end{array}$ & 7.10E-09 & $\begin{array}{l}-9.23 E-09 \\
(0.1834)\end{array}$ & $6.94 \mathrm{E}-09$ & $\begin{array}{l}-1.10 \mathrm{E}-08 \\
(0.1647)\end{array}$ & 7.93E-09 & $\begin{array}{l}-1.20 \mathrm{E}-08 \\
(0.2213)\end{array}$ & $9.82 \mathrm{E}-09$ \\
\hline LNASSETS & $\begin{array}{c}0.039 \\
(0.4260)\end{array}$ & $4.92 \mathrm{E}-02$ & $\begin{array}{c}0.027 \\
(0.5893)\end{array}$ & 0.0495 & $\begin{array}{c}0.020 \\
(0.6937)\end{array}$ & 0.050 & $\begin{array}{c}0.042 \\
(0.3967)\end{array}$ & 0.050 & $\begin{array}{c}0.038 \\
(0.4430)\end{array}$ & 0.050 \\
\hline $\begin{array}{l}\text { Industry Fixed Effects } \\
\text { Year Fixed Effects }\end{array}$ & $\begin{array}{l}\text { YES } \\
\text { YES }\end{array}$ & & $\begin{array}{l}\text { YES } \\
\text { YES }\end{array}$ & & $\begin{array}{l}\text { YES } \\
\text { YES }\end{array}$ & & $\begin{array}{l}\text { YES } \\
\text { YES }\end{array}$ & & $\begin{array}{l}\text { YES } \\
\text { YES }\end{array}$ & \\
\hline Constant & $\begin{array}{l}-0.673 \\
(0.4376)\end{array}$ & 0.867 & $\begin{array}{l}-0.695 \\
(0.4260)\end{array}$ & 0.873 & $\begin{array}{l}-0.470 \\
(0.5904)\end{array}$ & 0.874 & $\begin{array}{l}-0.727 \\
(0.4059)\end{array}$ & 0.875 & $\begin{array}{l}-0.803 \\
(0.3613)\end{array}$ & 0.879 \\
\hline Log Likelihood & -336.40 & & -331.70 & & -333.21 & & -336.34 & & -329.83 & \\
\hline McFadden R-squared & 0.014 & & 0.027 & & 0.023 & & 0.014 & & 0.033 & \\
\hline Target Prediction Rate & 49.390 & & 58.537 & & 56.504 & & 51.016 & & 54.878 & \\
\hline
\end{tabular}




\section{Table 3: Tobit Regression using Purchase Ratio}

This table presents the results of the tobit regressions conducted to test the effect of substantial shareholder purchase ratios on the bid premium. The regressions use a set of 251 target firms and 251 control firms that were listed on the ASX during the period 1/1/2010-31/12/2013. The dependent variable is the bid premium, the specific premium measure indicated in the panel name. PREM1 indicates the premium is calculated as the bid price divided by the price 1 day prior, PREM7 indicates the premium is calculated as the bid price divided by the price 7 days prior and PREM30 indicates the premium is calculated as the bid price divided by the price 30 days prior. PURCHASERATIO is the purchase ratio of the particular category of substantial shareholders, as indicated for the model winsorised at the $1 \%$ level. ROE is the return on equity for the firm. GROWEBIT is the firm's one year EBIT growth. LNPB is the log of the firm's price-to-book ratio. GROWSC is the ratio of the firm's one year operating revenue growth to the current ratio. NETINTCOV is the firm's net interest cover. LNASSETS is the log of the firm's total assets. Test statistics include relevant $p$-values (two-tailed) from robust standard errors. *,** and *** denote significance levels of $10 \%, 5 \%$ and $1 \%$ respectively.

\begin{tabular}{|c|c|c|c|c|c|c|c|c|}
\hline \multirow[b]{3}{*}{ Panel A: PREM1 } & \multicolumn{2}{|c|}{ Aggregate } & \multicolumn{2}{|c|}{ Fin. Institution } & \multicolumn{2}{|c|}{ Management } & \multicolumn{2}{|c|}{ Corporation } \\
\hline & Coef. & p. value & Coef. & p. value & Coef. & p. value & Coef. & p. value \\
\hline & & & & & & & & \\
\hline PURCHASERATIO & -0.090 & 0.1110 & $-0.120 * *$ & 0.0418 & -0.031 & 0.8198 & -0.081 & 0.2221 \\
\hline ROE & -0.037 & 0.5272 & -0.037 & 0.5128 & -0.029 & 0.6482 & -0.034 & 0.5588 \\
\hline GROWEBIT & -0.007 & 0.3367 & -0.010 & 0.2507 & -0.007 & 0.4054 & -0.006 & 0.1665 \\
\hline LNPB & -0.003 & 0.8154 & -0.002 & 0.8798 & -0.001 & 0.9052 & -0.002 & 0.8828 \\
\hline GROWSC & $0.001 * *$ & 0.0359 & $0.001 * *$ & 0.0467 & $0.001 * *$ & 0.0299 & $0.001 * *$ & 0.0221 \\
\hline NETINTCOV & $2.28 \mathrm{E}-09$ & 0.4781 & $2.55 \mathrm{E}-09$ & 0.4736 & $3.28 \mathrm{E}-09$ & 0.2661 & $3.05 \mathrm{E}-09$ & 0.2864 \\
\hline LNASSETS & -0.015 & 0.2640 & -0.012 & 0.3832 & -0.018 & 0.2189 & -0.017 & 0.2213 \\
\hline SCHEME & 0.067 & 0.1869 & 0.068 & 0.1809 & 0.058 & 0.2600 & 0.060 & 0.2489 \\
\hline CASH & -0.058 & 0.4884 & -0.074 & 0.3835 & -0.062 & 0.4580 & -0.058 & 0.4744 \\
\hline STOCK & $-0.213^{* *}$ & 0.0143 & $-0.221 * *$ & 0.0126 & $-0.212 * *$ & 0.0153 & $-0.212 * *$ & 0.0128 \\
\hline DRECOM & 0.057 & 0.2822 & 0.059 & 0.2570 & 0.057 & 0.2732 & 0.056 & 0.2859 \\
\hline Industry Fixed Effects & YES & & YES & & YES & & YES & \\
\hline Year Fixed Effects & YES & & YES & & YES & & YES & \\
\hline Constant & $0.290 * * *$ & 0.0000 & $0.289 * * *$ & 0.0000 & $0.292 * * *$ & 0.0000 & $0.291 * * *$ & 0.0000 \\
\hline N. of cases & 184 & & 184 & & 184 & & 184 & \\
\hline Pseudo R-squared & 0.254 & & 0.271 & & 0.232 & & 0.244 & \\
\hline
\end{tabular}




\begin{tabular}{|c|c|c|c|c|c|c|c|c|}
\hline \multirow[b]{3}{*}{ Panel B: PREM7 } & \multicolumn{2}{|c|}{ Aggregate } & \multicolumn{2}{|c|}{ Fin. Institution } & \multicolumn{2}{|c|}{ Management } & \multicolumn{2}{|c|}{ Corporation } \\
\hline & Coef. & p. value & Coef. & p. value & Coef. & p. value & Coef. & p. value \\
\hline & & & & & & & & \\
\hline PURCHASERATIO & -0.045 & 0.4749 & -0.039 & 0.5913 & -0.029 & 0.8150 & -0.041 & 0.5937 \\
\hline ROE & -0.064 & 0.2090 & -0.062 & 0.2237 & -0.056 & 0.2933 & -0.061 & 0.2366 \\
\hline GROWEBIT & $-0.017 *$ & 0.0880 & $-0.018^{*}$ & 0.0707 & $-0.016^{*}$ & 0.0971 & -0.016 & 0.1210 \\
\hline LNPB & $0.026 * * *$ & 0.0055 & $0.026^{* * *}$ & 0.0048 & $0.026 * * *$ & 0.0073 & $0.026 * * *$ & 0.0050 \\
\hline GROWSC & 0.001 & 0.1907 & 0.001 & 0.1945 & 0.001 & 0.1712 & 0.001 & 0.1542 \\
\hline NETINTCOV & $1.09 \mathrm{E}-09$ & 0.7976 & $1.35 \mathrm{E}-09$ & 0.7563 & $1.57 \mathrm{E}-09$ & 0.7042 & $1.54 \mathrm{E}-09$ & 0.7024 \\
\hline LNASSETS & -0.009 & 0.5338 & -0.008 & 0.5905 & -0.010 & 0.4977 & -0.009 & 0.5027 \\
\hline SCHEME & 0.098 & 0.1106 & 0.096 & 0.1150 & 0.093 & 0.1353 & 0.094 & 0.1317 \\
\hline CASH & 0.081 & 0.3445 & 0.076 & 0.3824 & 0.080 & 0.3522 & 0.080 & 0.3472 \\
\hline STOCK & -0.110 & 0.2228 & -0.111 & 0.2229 & -0.105 & 0.2425 & -0.106 & 0.2359 \\
\hline DRECOM & 0.060 & 0.3165 & 0.061 & 0.3108 & 0.061 & 0.3057 & 0.060 & 0.3163 \\
\hline Industry Fixed Effects & YES & & YES & & YES & & YES & \\
\hline Year Fixed Effects & YES & & YES & & YES & & YES & \\
\hline Constant & $0.357 * * *$ & 0.0000 & $0.357 * * *$ & 0.0000 & $0.357 * * *$ & 0.0000 & $0.357 * * *$ & 0.0000 \\
\hline N. of cases & 192 & & 192 & & 192 & & 192 & \\
\hline Pseudo R-squared & 0.136 & & 0.136 & & 0.134 & & 0.135 & \\
\hline
\end{tabular}




\begin{tabular}{|c|c|c|c|c|c|c|c|c|}
\hline & \multicolumn{2}{|c|}{ Aggregate } & \multicolumn{2}{|c|}{ Fin. Institution } & \multicolumn{2}{|c|}{ Management } & \multicolumn{2}{|c|}{ Corporation } \\
\hline & Coef. & p. value & Coef. & p. value & Coef. & p. value & Coef. & p. value \\
\hline \multicolumn{9}{|l|}{ Panel C: PREM30 } \\
\hline PURCHASERATIO & 0.002 & 0.9767 & -0.034 & 0.6077 & 0.027 & 0.8078 & -0.007 & 0.9408 \\
\hline ROE & $-0.123^{* *}$ & 0.0474 & $-0.126^{* *}$ & 0.0400 & $-0.124^{* *}$ & 0.0487 & $-0.124^{* *}$ & 0.0480 \\
\hline GROWEBIT & -0.010 & 0.2844 & -0.010 & 0.2542 & -0.011 & 0.2951 & -0.010 & 0.3448 \\
\hline LNPB & $0.038 * * *$ & 0.0000 & $0.037^{* * *}$ & 0.0000 & $0.038 * * *$ & 0.0001 & $0.038 * * *$ & 0.0000 \\
\hline GROWSC & 0.001 & 0.3521 & 0.001 & 0.3858 & 0.001 & 0.3409 & 0.001 & 0.3509 \\
\hline NETINTCOV & $3.88 \mathrm{E}-09$ & 0.2970 & $3.64 \mathrm{E}-09$ & 0.3445 & 3.87E-09 & 0.2943 & $3.84 \mathrm{E}-09$ & 0.2986 \\
\hline LNASSETS & -0.001 & 0.9669 & 0.001 & 0.9582 & $-9.60 \mathrm{E}-05$ & 0.9953 & -0.001 & 0.9671 \\
\hline SCHEME & 0.104 & 0.1075 & 0.106 & 0.1022 & 0.104 & 0.1072 & 0.104 & 0.1079 \\
\hline $\mathrm{CASH}$ & 0.036 & 0.6737 & 0.033 & 0.6954 & 0.036 & 0.6721 & 0.037 & 0.6682 \\
\hline STOCK & -0.121 & 0.1792 & -0.124 & 0.1672 & -0.121 & 0.1791 & -0.121 & 0.1797 \\
\hline DRECOM & 0.096 & 0.1416 & 0.096 & 0.1441 & 0.096 & 0.1429 & 0.096 & 0.1420 \\
\hline Industry Fixed Effects & YES & & YES & & YES & & YES & \\
\hline Year Fixed Effects & YES & & YES & & YES & & YES & \\
\hline Constant & $0.350 * * *$ & 0.0000 & $0.350 * * *$ & 0.0000 & $0.350 * * *$ & 0.0000 & $0.350 * * *$ & 0.0000 \\
\hline N. of cases & 187 & & 187 & & 187 & & 187 & \\
\hline Pseudo R-squared & 0.189 & & 0.190 & & 0.189 & & 0.189 & \\
\hline
\end{tabular}




\section{Table 4: Robustness - Tobit Regression Subsample Analysis using Purchase Ratio by High and Low Premium Bids}

This table presents the results of the Tobit regressions conducted to test the effect of substantial shareholder purchase ratio on the bid premium. The regressions use a set of 251 target firms and 251 control firms that were listed on the ASX during the period 1/1/2010-31/12/2013. The dependent variable is the bid premium, the specific premium measure indicated in the panel name. The sample is split into high and low premium bids by the mean premium. PREM1 indicates the premium is calculated as the bid price divided by the price 1 day prior, PREM7 indicates the premium is calculated as the bid price divided by the price 7 days prior and PREM 30 indicates the premium is calculated as the bid price divided by the price 30 days prior. PURCHASERATIO is the purchase ratio of the particular category of substantial shareholders, as indicated for the model winsorised at the $1 \%$ level. ROE is the return on equity for the firm. GROWEBIT is the firm's one year EBIT growth. LNPB is the log of the firm's price-to-book ratio. GROWSC is the ratio of the firm's one year operating revenue growth to the current ratio. NETINTCOV is the firm's net interest cover. LNASSETS is the log of the firm's total assets. Test statistics include relevant $p$-values (two-tailed) from robust standard errors. *, ** and *** denote significance levels of $10 \%, 5 \%$ and $1 \%$ respectively.

\begin{tabular}{|c|c|c|c|c|c|c|c|c|}
\hline & \multicolumn{4}{|c|}{ Aggregate } & \multicolumn{4}{|c|}{ Financial Institutions } \\
\hline & \multicolumn{2}{|c|}{ High Premium } & \multicolumn{2}{|c|}{ Low Premium } & \multicolumn{2}{|c|}{ High Premium } & \multicolumn{2}{|c|}{ Low Premium } \\
\hline & Coef. & p. value & Coef. & p. value & Coef. & p. value & Coef. & p. value \\
\hline \multicolumn{9}{|l|}{ Panel A: PREM1 } \\
\hline PURCHASERATIO & 0.035 & 0.3112 & 0.005 & 0.9427 & -0.004 & 0.8933 & -0.056 & 0.4553 \\
\hline ROE & 0.011 & 0.7829 & $-0.084 *$ & 0.0616 & 0.003 & 0.9345 & $-0.085^{*}$ & 0.0646 \\
\hline GROWEBIT & $-0.001 * *$ & 0.0396 & -0.019 & 0.2788 & $-0.001 * *$ & 0.0189 & -0.019 & 0.2255 \\
\hline LNPB & 0.003 & 0.3646 & -0.005 & 0.7291 & 0.002 & 0.4735 & -0.006 & 0.7202 \\
\hline GROWSC & $0.001 * *$ & 0.0360 & 0.000 & 0.6878 & $0.001^{*}$ & 0.0746 & 0.000 & 0.7063 \\
\hline NETINTCOV & $9.42 \mathrm{E}-10$ & 0.3807 & 4.37E-09 & 0.2614 & $7.22 \mathrm{E}-10$ & 0.5240 & 2.27E-09 & 0.6114 \\
\hline LNASSETS & 0.004 & 0.5835 & $-0.042 * *$ & 0.0134 & 0.005 & 0.5301 & $-0.039 * *$ & 0.0255 \\
\hline SCHEME & -0.028 & 0.3594 & 0.035 & 0.5286 & -0.019 & 0.5223 & 0.036 & 0.5158 \\
\hline CASH & $0.072 *$ & 0.0745 & -0.079 & 0.3738 & $0.071 *$ & 0.0900 & -0.086 & 0.2931 \\
\hline STOCK & 0.016 & 0.7087 & $-0.158^{*}$ & 0.0641 & 0.015 & 0.7368 & $-0.164 *$ & 0.0532 \\
\hline DRECOM & 0.010 & 0.7161 & 0.003 & 0.9433 & 0.012 & 0.6616 & 0.005 & 0.9177 \\
\hline Industry Fixed Effects & YES & & YES & & YES & & YES & \\
\hline Year Fixed Effects & YES & & YES & & YES & & YES & \\
\hline Constant & $0.114 * * *$ & 0.0000 & $0.202 * * *$ & 0.0000 & $0.114^{* * *}$ & 0.0000 & $0.201 * * *$ & 0.0000 \\
\hline N. of cases & 97 & & 87 & & 97 & & 87 & \\
\hline Pseudo R-squared & -0.328 & & -6.306 & & -0.315 & & -6.482 & \\
\hline
\end{tabular}




\begin{tabular}{|c|c|c|c|c|c|c|c|c|}
\hline & \multicolumn{4}{|c|}{ Aggregate } & \multicolumn{4}{|c|}{ Financial Institutions } \\
\hline & \multicolumn{2}{|c|}{ High Premium } & \multicolumn{2}{|c|}{ Low Premium } & \multicolumn{2}{|c|}{ High Premium } & \multicolumn{2}{|c|}{ Low Premium } \\
\hline & Coef. & p. value & Coef. & p. value & Coef. & p. value & Coef. & p. value \\
\hline \multicolumn{9}{|l|}{ Panel B: PREM7 } \\
\hline PURCHASERATIO & 0.034 & 0.4177 & 0.016 & 0.8484 & -0.019 & 0.6445 & 0.007 & 0.9427 \\
\hline ROE & -0.059 & 0.2342 & -0.083 & 0.1877 & -0.068 & 0.1429 & -0.084 & 0.1947 \\
\hline GROWEBIT & -0.002 & 0.1481 & $-0.045 * * *$ & 0.0069 & $-0.002 * *$ & 0.0256 & $-0.045 * * *$ & 0.0070 \\
\hline LNPB & $0.040 * * *$ & 0.0000 & 0.012 & 0.4406 & $0.039 * * *$ & 0.0000 & 0.012 & 0.4356 \\
\hline GROWSC & 0.000 & 0.8084 & 0.001 & 0.3767 & 0.000 & 0.6254 & 0.001 & 0.3777 \\
\hline NETINTCOV & $2.52 \mathrm{E}-09 *$ & 0.0728 & $-1.20 \mathrm{E}-08$ & 0.3122 & 2.33E-09 & 0.1365 & $-1.21 \mathrm{E}-08$ & 0.3070 \\
\hline LNASSETS & 0.018 & 0.1584 & $-0.055^{* *}$ & 0.0194 & 0.019 & 0.1356 & $-0.055^{* *}$ & 0.0224 \\
\hline SCHEME & -0.014 & 0.7040 & 0.125 & 0.1499 & -0.002 & 0.9602 & 0.124 & 0.1473 \\
\hline CASH & $0.162^{* * *}$ & 0.0027 & 0.164 & 0.1048 & $0.161^{* * *}$ & 0.0037 & 0.166 & 0.1057 \\
\hline STOCK & 0.056 & 0.2226 & -0.003 & 0.9762 & 0.054 & 0.2483 & -0.004 & 0.9664 \\
\hline DRECOM & 0.032 & 0.3008 & -0.063 & 0.4204 & 0.034 & 0.2769 & -0.064 & 0.4165 \\
\hline Industry Fixed Effects & YES & & YES & & YES & & YES & \\
\hline Year Fixed Effects & YES & & YES & & YES & & YES & \\
\hline Constant & $0.141^{* * *}$ & 0.0000 & $0.311^{* * *}$ & 0.0000 & $0.141 * * *$ & 0.0000 & $0.311^{* * *}$ & 0.0000 \\
\hline N. of cases & 97 & & 95 & & 97 & & 95 & \\
\hline Pseudo R-squared & -2.234 & & 0.330 & & -2.215 & & 0.330 & \\
\hline
\end{tabular}




\begin{tabular}{|c|c|c|c|c|c|c|c|c|}
\hline \multirow[b]{3}{*}{ Panel C: PREM30 } & \multicolumn{4}{|c|}{ Aggregate } & \multicolumn{4}{|c|}{ Financial Institution } \\
\hline & \multicolumn{2}{|c|}{ High Premium } & \multicolumn{2}{|c|}{ Low Premium } & \multicolumn{2}{|c|}{ High Premium } & \multicolumn{2}{|c|}{ Low Premium } \\
\hline & Coef. & p. value & Coef. & p. value & Coef. & p. value & Coef. & p. value \\
\hline PURCHASERATIO & 0.081 & 0.1728 & 0.047 & 0.6158 & -0.011 & 0.8479 & 0.020 & 0.8167 \\
\hline ROE & $-0.125^{*}$ & 0.0693 & -0.041 & 0.4136 & $-0.143^{* *}$ & 0.0402 & -0.040 & 0.4365 \\
\hline GROWEBIT & -0.004 & 0.2946 & -0.027 & 0.1066 & $-0.004 * *$ & 0.0494 & $-0.028 *$ & 0.0867 \\
\hline LNPB & $0.050 * * *$ & 0.0000 & $0.033^{*}$ & 0.0544 & $0.048 * * *$ & 0.0000 & $0.033^{*}$ & 0.0529 \\
\hline GROWSC & $-0.004 * *$ & 0.0105 & $0.001 * *$ & 0.0442 & $-0.004 * * *$ & 0.0058 & $0.001 * *$ & 0.0469 \\
\hline NETINTCOV & $2.33 \mathrm{E}-09$ & 0.2653 & $-4.37 E-09$ & 0.5023 & $1.81 \mathrm{E}-09$ & 0.4311 & $-4.68 \mathrm{E}-09$ & 0.4891 \\
\hline LNASSETS & 0.017 & 0.2668 & $-0.041 * *$ & 0.0319 & 0.019 & 0.2179 & $-0.041 * *$ & 0.0349 \\
\hline SCHEME & 0.018 & 0.7224 & 0.091 & 0.3248 & 0.041 & 0.4220 & 0.088 & 0.3373 \\
\hline CASH & $0.170 * *$ & 0.0159 & -0.002 & 0.9819 & $0.162 * *$ & 0.0284 & 0.005 & 0.9632 \\
\hline STOCK & 0.089 & 0.1903 & -0.124 & 0.3008 & 0.082 & 0.2567 & -0.126 & 0.2946 \\
\hline DRECOM & 0.033 & 0.4414 & -0.003 & 0.9687 & 0.038 & 0.3853 & -0.008 & 0.9154 \\
\hline Industry Fixed Effects & YES & & YES & & YES & & YES & \\
\hline Year Fixed Effects & YES & & YES & & YES & & YES & \\
\hline Constant & $0.199 * * *$ & 0.0000 & $0.315^{* * *}$ & 0.0000 & $0.201^{* * *}$ & 0.0000 & $0.315^{* * *}$ & 0.0000 \\
\hline N. of cases & 95 & & 92 & & 95 & & 92 & \\
\hline Pseudo R-squared & 1.438 & & 0.376 & & 1.390 & & 0.373 & \\
\hline
\end{tabular}

